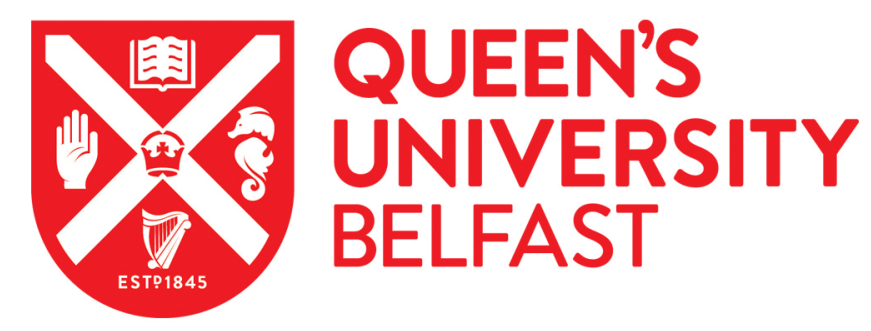

\title{
Resolving international border disputes: the Irish experience
}

Coakley, J. (2017). Resolving international border disputes: the Irish experience. Cooperation and Conflict, 52(3), 377-398. https://doi.org/10.1177/0010836716684881

Published in:

Cooperation and Conflict

Document Version:

Peer reviewed version

Queen's University Belfast - Research Portal:

Link to publication record in Queen's University Belfast Research Portal

Publisher rights

Copyright $\odot 2016$, The Authors.

This work is made available online in accordance with the publisher's policies.

\section{General rights}

Copyright for the publications made accessible via the Queen's University Belfast Research Portal is retained by the author(s) and / or other copyright owners and it is a condition of accessing these publications that users recognise and abide by the legal requirements associated with these rights.

Take down policy

The Research Portal is Queen's institutional repository that provides access to Queen's research output. Every effort has been made to ensure that content in the Research Portal does not infringe any person's rights, or applicable UK laws. If you discover content in the Research Portal that you believe breaches copyright or violates any law, please contact openaccess@qub.ac.uk. 


\title{
RESOLVING INTERNATIONAL BORDER DISPUTES: THE IRISH EXPERIENCE
}

\author{
John Coakley \\ Queen's University Belfast \\ University College Dublin
}

Published in Cooperation and Conflict, 17 Jan. 2017 (Online First);

DOI: 10.1177/0010836716684881

\begin{abstract}
The literature on international border disputes has in recent years focused increasingly on the role played by norm transition in promoting or facilitating new political compromises. This article explores the value of a specific model of norm replacement in accounting for the circumstances leading to Ireland's Good Friday agreement in 1998, which formally and finally settled the long-running territorial dispute between Ireland and the United Kingdom. Drawing on the theoretical literature, it identifies three phases in this process. First, from the creation of the Irish Free State in 1922 until the civil unrest in Northern Ireland peaked in 1972 the irredentist norm was substantially unchallenged. It was embedded in the 1937 constitution, which defined the national territory as extending over the whole island of Ireland-including Northern Ireland, a part of the United Kingdom. The second phase, from about 1972 to 1998, was one of norm competition. The irredentist norm was severely challenged by new political realities in Northern Ireland, and was potentially destabilising for the state itself. It was increasingly challenged by an alternative 'consent' norm, one embracing in effect the geopolitical status quo. The third phase, from 1998 onwards, was one of consolidation of the new norm, now written into the Irish constitution to replace the wording of 1937 . The article suggests that this model plays a valuable role in accounting for the changing status of the Irish border, but also that the Irish experience has implications for the broad shape of the model.
\end{abstract}

Key words: partition, boundary disputes, territorial politics, Northern Ireland, United Kingdom, Republic of Ireland.

\section{Introduction}

How do states which share a disputed frontier come eventually to an accommodation on an agreed line of demarcation? An important recent review of the nexus between borders, conflict and trade concluded that, while significant advances have been made in explaining the endurance of territorial disputes between states, it is much more difficult to account for the factors that facilitate the resolution of conflicts of this kind (Schultz, 2015: 141). This article considers one such protracted stand-off that came to a sudden end: the British-Irish dispute over the territory of Northern Ireland. This case is an important one because of its longevity (extending from 1922 to 1998), its intensity (marked by profoundly diverging nationalist values, sharply clashing constitutional claims, and a violent conflict that resulted in hundreds of deaths in the 1920s and thousands in the period 1968-98), and its geopolitical location (in the otherwise relatively peaceful northwestern corner of Europe). It also raises challenging theoretical questions: about the structure of elite-driven ideology (the mechanics of ideological shift and the character of elite discourse), about the nature of borders (their permeability or otherwise, and their symbolic and substantive significance), and about the character of any settlement (whether definitive, transitional, or inherently unstable).

This article tries to account for the outcome in the Irish case in the context of current comparative research in this area, and to explore its implications for this literature. It begins by examining recent findings on the resolution of territorial border disputes that offer insights into the Northern Irish case. It continues by outlining the range of geopolitical models that 
have been at the core of efforts at settlement. It goes on to look at the process by which the Irish political elite apparently moved from a preference for one of these models to a preference for another quite different one in three phases: from independence in 1922 to the collapse of Northern Ireland's self-governing institutions in 1972, from then to the Good Friday agreement of 1998, and in the aftermath of the agreement. It concludes by assessing the contribution of this case to broader comparative models of territorial conflict resolution.

Of necessity, the article minimises discussion of an important background factor: the historical relationship of political dependence of Dublin on London, a matter of obvious importance up to 1936, but not devoid of significance since then. It also avoids addressing a core problem, the intercommunal conflict in Northern Ireland, except when this impinges on the cross-border tension analysed here. ${ }^{1}$ It also focuses, again with a view to ensuring the manageability of the topic, on the perspective of the Republic of Ireland rather than of the United Kingdom (on changing British perspectives, see Tannam, 2001; Todd, 2014, 2016b).

\section{Legitimising disputed boundaries}

At a time when it was thought that the collapse of communism and the disintegration of the Soviet Union would result in a proliferation of territorial disputes, observers expressed surprise that the ultimate outcome was so peaceful. The highly visible human and economic costs of the turmoil in such cases as Ukraine (Dragneva and Solczuk, 2015: 100-106) have distracted attention from the reality that there have been far fewer territorial disputes than might have been expected. Forsberg (1998: 437-8) has identified three approaches to explaining this, corresponding approximately to liberal, realist and constructivist perspectives. The first sees the drive for territorial expansion as being undermined by relationships between 'trading states', where trade relations take priority. Second, power relations may render conflict less desirable, reducing the incentives for continuing conflict in circumstances where neither side is prepared to budge. Third, new identity patterns may serve to legitimise the territorial status quo (Forsberg, 1998: 437-8).

'Liberal' or economic arguments may indeed have a role to play, but it is a paradoxical one in the Irish case. It seems clear that the prospect of joint economic gains incentivises settlement (Schultz, 2015: 141), and that opportunities in the areas of trade, investment, travel and tourism encourage the normalisation of political relations (Simmons, 2005: 843). The sheer military and financial costs of maintaining a dispute further reduce the attractiveness of this course of action to the challenging state (Wiegand, 2011: 279-80). At first sight, though, the broad shape of the Irish-British economic relationship gives the lie to this. Trading and other economic links between the two states were remarkably high from the 1920 s to the 1960s, with massive Irish trade dependence on the UK; this dependence fell below 50\% in respect of both exports and imports only in the1970s (Bradley, 2007: 66-67). But Irish irredentist rhetoric was at its height during the first period, and began to soften only during the 1970s, precisely as Irish dependence on the British market fell. Close trade relationships and economic exchange, it seems, may promote, and be facilitated by, political normalisation; but they will not of themselves necessarily prevent interstate conflict.

Realist arguments suggest that neither side to a territorial boundary dispute has much to gain from prolonged stalemate (Simmons, 2005: 827). Predictability in the international territorial order is also desirable from the perspective of neighbouring states (Zacher, 2001: 234-5), and in any case international law has been moving in the direction of stressing the legitimacy of existing territorial borders (Abulof, 2016; Finnemore and Sikkink, 1998). It seems likely that the Irish-British relationship has not been immune from this pressure to settle, a pressure that would have been all the more immediate and explicit after the two states became fellowmembers of the EU in 1973 (Hayward, 2006, 2009; McCall, 2011, 2014; Tannam, 2007a).

The constructivist position focuses on changing mass and elite attitudes. One influential approach to the explanation of the role of new norms in international relations suggests that they pass through a life cycle with three stages: (1) emergence, as 'norm entrepreneurs' try 
to persuade a critical mass of other actors to accept their new norm, (2) acceptance, as the new norm acquires a dominant position, characterised by 'cascading' support from a growing number of actors, often marked by a 'tipping point' at which support from a critical mass of actors has been achieved, and (3) internalisation, where the norm has been so fully accepted that it no longer needs to be articulated frequently, but is simply taken for granted (Finnemore and Sikkink, 1998: 895). This framework has been used to account for the manner in which the norm of territorial integrity (the notion that existing state boundaries should be accepted) has gained general acceptance, through (1) emergence of the notion of respect for the territorial integrity of existing states, expressed initially in the League of Nations Covenant, (2) acceptance of this principle in such documents as the UN Charter (1945), and subsequent endorsement by most states, and (3) strengthening of this norm from 1976 onwards, and universal adherence to it in international relations (Zacher, 2001: 236-7).

This model may be used not just to account not only for the emergence of new international norms advocated by states but also for the emergence of new policy norms advanced by groups and individuals within states. A very similar three-stage approach, based on patterns of argumentation at elite level, has been used to explain acceptance of the territorial status quo norm at national level, illustrated by the Irish case. This again identified three stages in the war of ideas: (1) innovative argumentation, which questions the accepted norm as existing realities shift, often triggered by a revolutionary event and marked by a 'cognitive punch' (which makes it clear that 'old ways of doing things are obsolete and have to be replaced by something new'), (2) persuasive argumentation, in which a compelling link between the new norm and actors' everyday experiences is established, and (3) compromise with remaining opponents of the new norm, who are overwhelmed by the dominance of the new majority viewpoint and are unwilling to pay the costs of opposing it (Kornprobst, 2007a: 70-71, 78). In the Irish case, the old norm rested on a profound commitment in the South to the territorial claim over Northern Ireland, with those who broke this taboo vilified as traitors. The outbreak of civil unrest in 1968 was the 'revolutionary event' that made it clear that 'the old ways of doing things had become obsolete', and advocates of the new norm-the territorial status quo-were able to bring large segments of the elites and the general public along with them. Finally, the new norm was embedded in the Good Friday agreement in 1998 and fully accepted in the Republic, with opponents bending to the new dominant view (Kornprobst, 2007a: 72, 92-3).

There is, then, a prima facie case for using the Irish experience to test this set of generalisations, and to do so by recognising three phases. The first, from independence in 1922 down to the early 1970s, was one in which the irredentist norm was dominant. The period from then until about 1998 was one of competition between this norm and an alternative that was relatively new to Ireland, that of the territorial status quo. The decisive victory of the latter in the 1998 negotiations has been marked by the subsequent neardisappearance of its competitor.

\section{Geopolitical models of dispute management}

It has been argued that, apart from a few circumstances such as when one state leases part of another, conflicts over territory are primarily zero-sum, in that 'usually only one entity can control a piece of land' (Goertz and Diehl, 1992: 51). While this may reflect the rhetoric of the states which are parties to the dispute, alternative compromise strategies are available, including fair division, joint management and the creation of neutral, buffer or demilitarised zones (Guo, 2012: 85-30). Partition and joint rule are thus alternatives to handing a disputed territory to one of the two claimant states. Repartition was on the Irish political agenda in the early 1920s (with nationalist leaders expecting that a boundary commission would make substantial territorial awards to the South). Though abandoned in 1925, the idea of repartition resurfaced occasionally in the 1970s and 1980s (see Kennedy, 1990). 
The notion of shared authority was particularly important in the Irish case, since it assisted the compromise reached in 1998. Because of the important role they played in facilitating inter-state compromise, it is important to consider further models that sought to undermine the zero-sum perception of what was at stake (for an overview of approaches, see Wolff, 2003: 16-33). Figure 1 presents schematically the range of relationships that may emerge. In principle, in disputes over territory $X$ between states $Y$ and $Z$, four types of outcome are possible: either $Y$ or $Z$ gains (or retains) control, or both do (sharing sovereignty over $X$ ), or neither does ( $X$ becomes independent). It is, however, also possible to envisage certain intermediate categories, as the figure shows. 


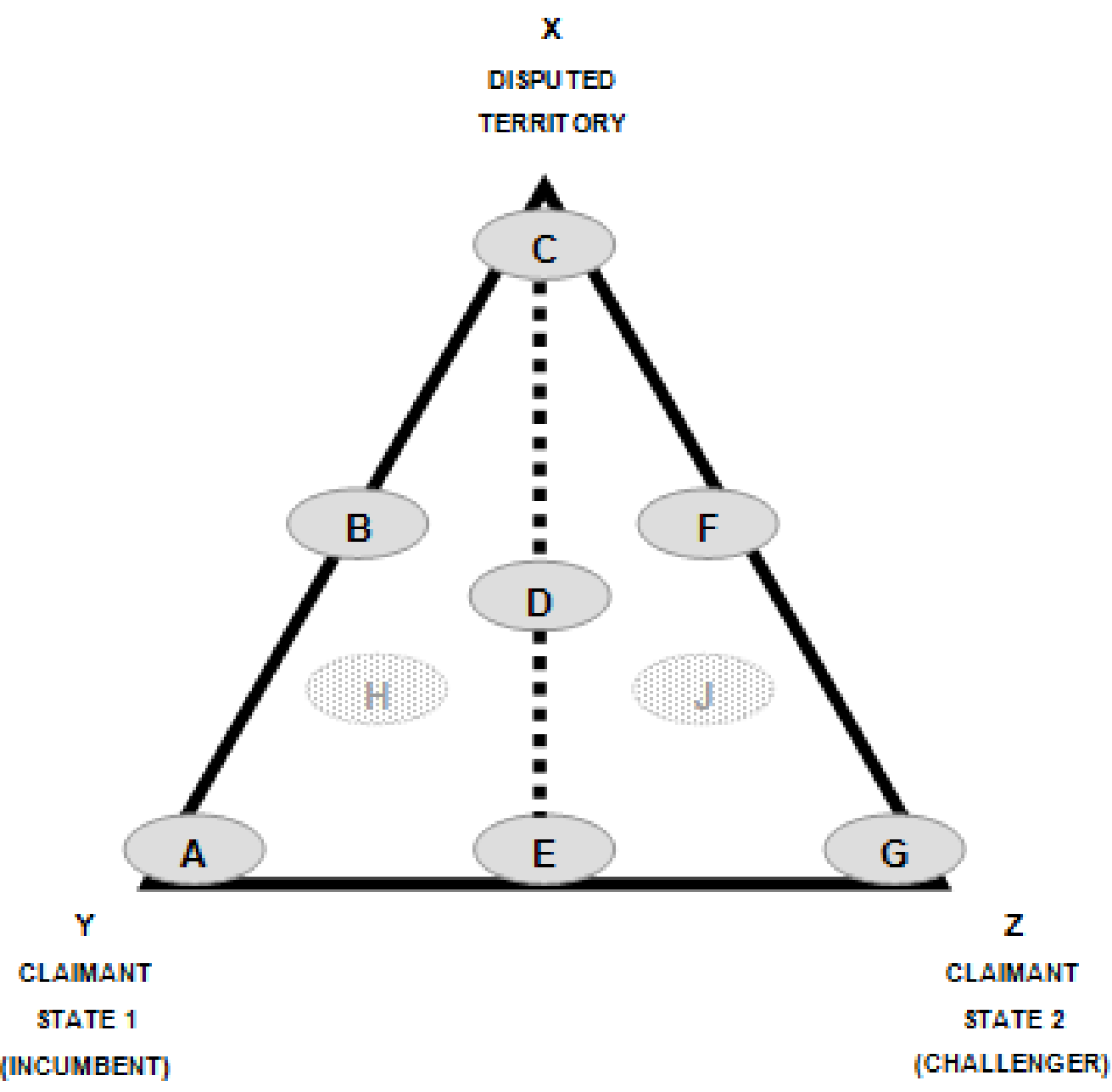

Eigure 1. Potential power. relationships. between a disputed tercitor $x$ and clainant states .

Note: The trlangle's ver tces indicate concentration of power and the other positions varlous combinations of power.

In very many cases, incumbent state $\mathrm{Y}$ exercises direct control over disputed territory $\mathrm{X}$, as in interwar Czechoslovakia's rule over the predominantly German-speaking districts of Bohemia and Moravia (position A; Wiskemann, 1967: 97-139). Often, though, the incumbent sovereign makes significant concessions to the disputed territory as a gesture to the challenging claimant and to circumstances in the disputed territory, as in Finland's concession in 1920 of very substantial autonomy to the Åland Islands, with their cultural and historical links to Sweden (position B; Hepburn, 2014). Mirroring these positions, claimant state $\mathrm{Z}$ may win complete control over the disputed territory, which it then administers as an integral part of the state (position G), as in the French annexation of Alsace-Lorraine in 1918 (Wolff, 2003: 39-79). In other circumstances, while the claimant state achieves overall control of territory $\mathrm{X}$, it concedes substantial autonomy to that state, as in South Tyrol in Italy (which moved from position $G$ to position $F$, with its special status recognised in stages; Grote, 2012; Wolff, 2008). In between these, positions C, D and E represent balanced compromises between the two claimant states, differing only in the level of autonomy conferred on the disputed territory. The two states may both entirely surrender sovereignty over territory $\mathrm{X}$, as 
Germany and Poland did in respect of the Free City of Danzig after 1920 (position C; Oberdörfer, 2014); they may continue to exercise at least nominal sovereignty over a selfgoverning territory, as in the titular sovereignty of the French President and the Bishop of Urgell in Spain over Andorra after 1993 (position D; Wolff, 2003: 197-9); or they may rule the disputed territory jointly and directly, as the British and French did in respect of the New Hebrides (now Vanuatu) up to 1980 (position E; Wolff, 2003: 200-205; see also Samuels, 2007).

In the context of British and Irish claims to Northern Ireland, these positions translate into a set of clearly recognisable policy stances, most of which were identified at an early stage in the literature on the Northern Ireland conflict (Rose, 1976: 139-66; McGarry and O'Leary, 1990: 269-89; Whyte, 1990: 209-43).

A. Integration within the United Kingdom. Northern Ireland $(X)$ is governed as an integral part of the incumbent state $(\mathrm{Y})$. Though widely canvassed, especially by unionists in the 1980s, this position has been emphatically rejected by the British government; the whole thrust of constitutional evolution in the UK since the late twentieth century has been away from integration. However, something close to this, direct rule, has been the default British position, implemented pragmatically in 1972-73, 1974-99 and 2002-07. It is a conceivable long-term constitutional option that differs from integration in that Northern Ireland would continue with its own distinct corpus of laws and administrative arrangements (Aughey, 1989: 132-167; Roberts, 1987).

B. Devolution within the United Kingdom. Northern Ireland forms part of the United Kingdom, with which it has a federative relationship: the UK government controls foreign affairs, defence and certain other services, while the Northern Ireland government controls domestic services, as in the case of the component members of federations. This is the position that obtained from 1921 to 1972 (based on the principle of majority rule in Northern Ireland) and in 1974, 1999-2002 and from 2007 to the present (now based on consociation within Northern Ireland, and with a higher level of British involvement; see Knox, 2010: 7-46; Aughey, 1989: 99-131).

C. An independent Northern Ireland. Northern Ireland is independent of both the Republic of Ireland and the United Kingdom. Under the premiership of Lord Brookeborough (1943-63), the Northern Ireland government briefly considered leaving the UK and joining the Commonwealth, and an independent Northern Ireland was actively considered by certain unionist politicians in the mid-1970s-notably by the breakaway Vanguard Unionist Party. This option was also contemplated by Harold Wilson's Labour government in 1974-75, though had this been pursued it is likely that Wilson would have pressed the Irish government to assume responsibility for Northern Ireland. Variants include a unilateral declaration of independence (favoured by some unionists in the 1970s), and negotiated independence, with continuing British subsidies (Moore and Crimmins, 1990).

$D$. Devolution with joint British-Irish rule. Institutions of government within Northern Ireland (whether based on majoritarian or consociational principles) exercise the functions outlined in $\mathrm{B}$ above; sovereign responsibility is shared by the British and Irish governments. This was advocated by the SDLP as a transitional mechanism towards Irish unity (1972), and was considered as a long-term solution by the all-party New Ireland Forum (1984) in the Republic. It was analysed from an academic perspective by Dent (1988) and Kenny (1990), and O'Leary et al (1993: 23-49) elaborated a detailed model with significant domestic input.

E. Direct British-Irish condominium. Sovereign responsibility is shared by the British and Irish governments, without any devolved institutions within Northern Ireland. This has attracted support from the same sources as D (for a variant, see Hayes, 1998).

F. Devolution within a united Ireland. Northern Ireland forms part of the Republic, with which it has a federative relationship. This is the mirror-image of $B$, and was the solution overtly preferred by de Valera and written into the 1937 constitution: Westminster would transfer its sovereign powers to Dublin. The New Ireland Forum presented a variant of this: a new all- 
Irish state would be created as a symmetrical federation (or even confederation), with the two component parts of equal status (for a critique, see Palley, 1990: 93-94). In yet another variant, Sinn Féin's Eire Nua policy (1971) also proposed a symmetrical federation based on the four historical provinces, with Northern Ireland expanding to be replaced by the province of Ulster.

G. A unitary Irish state. Northern Ireland is governed as an integral part of the Republic. This is the mirror-image of $A$, and was the implicit preference of pre-partition Sinn Féin, and, under pressure from Charles Haughey and his Fianna Fáil party, it was adopted as the preferred option of the New Ireland Forum. Advocated by many traditional nationalists, it has been elaborated by Anthony Coughlan (1990), who pointed out that constitutional amendment could also allow for island-level power sharing, at least on a transitional basis.

These positions may appear complex, but in reality they oversimplify the range of available options. In the triangle in figure 1, the sides CA and CG, and the median line CE, are each a continuum, rather than, as presented here, a three-point scale (all power - some power - no power); a particular settlement may move along them by degrees. Furthermore, particular political settlements may lie between these lines rather than on them; the structures established by the Good Friday agreement, for instance, lie somewhere in the middle of the quadrilateral ABDE rather than matching any of the positions identified there (here, position $\mathrm{H}$ has been suggested). It should also be noted that this framework focuses on the formal balance of power; it ignores the significance of other factors such as de facto asymmetrical power relationships between states (a consideration of particular importance in the BritishIrish relationship) and the impact of co-membership of larger geopolitical entities such as the $\mathrm{EU}$, which compromise the sovereignty of each state and transform the nature of the border between them (Coakley and O'Dowd, 2007; Tannam, 2007b).

\section{The unity norm}

For the first five decades of the life of the new Irish state, the norm of Irish unity remained supreme, at least at the rhetorical level. The 'home rule' (devolution) programme of the (mainly Catholic) Irish Nationalist Party, which had dominated the politics of the island since the 1880s, had fallen foul of powerful Protestant opposition concentrated in the North East. When the Nationalist Party was overwhelmed in 1918 by a more radical force, the separatist Sinn Féin party, the problem of reaching an accommodation with the North East was passed on, but now in a more demanding form, since the stakes were higher: nationalist demands for devolution had been replaced by demands for independence. The ultimate outcome was partition of the island, introduced as part of a devolution settlement in 1921, with the North East becoming a devolved region of the United Kingdom, Northern Ireland. Devolution proved ineffective in the South; instead, a new settlement, the Anglo-Irish Treaty of 1921 negotiated by the Sinn Féin leadership and the British government, allowed it to leave the United Kingdom, to become a British dominion modelled on Canada, known as the Irish Free State.

The line of the boundary that separated the Free State from its now truncated parent state, the United Kingdom, was objectionable to Irish nationalists for two main reasons. First, it violated what they saw as the 'historic national territory', the home of the Irish, the island of Ireland-an expression of classic nationalist attachment to a specific area, regardless of its ethnic make-up, comparable with that associated with other nationalist movements, such as those of the Czechs, Finns, Lithuanians and Hungarians (Coakley, 2012: 109-111). Second, the line of the Irish border was manifestly biased, in that it diverged substantially from the (already imprecise) ethnic frontier (Rankin, 2007: 910-16). The territory that was allowed to opt out of the Free State was enlarged to include not just two overwhelmingly Protestant counties, but also four mixed ones, in two of which Catholics outnumbered Protestants, resulting in an overall Catholic minority of $34 \%$. 
Two provisions of the 1921 Treaty that immediately called the status of the border into question ironically had the long-term effect of consolidating it. First, provision was made for a Council of Ireland, representing the two parts of island, that would initially have limited powers, but with capacity to expand these. Second, the line of the border would be examined by a boundary commission, whose terms of reference enjoined it to take account of 'the wishes of the inhabitants'; but only 'in so far as may be compatible with economic and geographic conditions', a phrase whose meaning was unclear (Blake, 1996). Ultimately, the commission adopted a very conservative approach, favouring only minor adjustments to the line of the border; and the Council of Ireland, never popular with nationalists because it symbolised partition and gave unionists undue influence, never came into existence. A tripartite conference between the British, Irish and Northern Irish prime ministers in 1925 agreed to leave the existing border unaltered and to abandon the Council of Ireland.

The political history of the first 15 years of the Irish Free State was dominated by efforts to assert its complete independence, even if this was at the cost of hardening the border. These were accompanied by vocal denunciations of partition and demands for Irish unity, led initially by the pro-Treaty wing of Sinn Féin (now Fine Gael), and then by its successor in government in 1932, Fianna Fáil, the long-standing dominant force in Irish politics. ${ }^{2}$ The party leader, de Valera, devised a distinctive formula for unity, one which he outlined initially during the debates on the Treaty in 1921-22, but which continued to be party policy until the 1960s: London would transfer its sovereign powers over Northern Ireland to Dublin, but devolved institutions would continue to function in Belfast.

The constitution of the Irish Free State (adopted in 1922, and explicitly subject to the 1921 Treaty) was a further target of de Valera He secured enactment of a new constitution in 1937, one presented as a foundation document comparable with other revolutionary constitutions (see Ackerman, 1992: 49-50). As well as renaming the state 'Ireland' (it was not designated a republic until 1949), it boldly asserted the territorial integrity of the island of Ireland, in articles whose substantive significance is less clear than their symbolic import:

Article 2. The national territory consists of the whole island of Ireland, its islands and the territorial seas.

Article 3. Pending the re-integration of the national territory, and without prejudice to the right of the parliament and government established by this constitution to exercise jurisdiction over the whole territory, the laws enacted by the parliament shall have the like area and extent of application as the laws of Saorstát Éireann [the Irish Free State] and the like extra-territorial effect.

But very little of substance followed. The unexpected decision in 1948 to proclaim Ireland a republic was made by a Fine Gael-led coalition, and took effect at the same time as a flurry of anti-partition activity. This included foreign tours by de Valera denouncing the evils of partition in 1948-51, and the creation of an All-Party Anti-Partition Conference in 1949. This produced a number of propagandist works, including a substantial volume in the name of its secretary, Frank Gallagher (1957). Its views on partition were predictable: it was a 'denial of the right to self-determination'-a refusal, imposed and supported by the British government, to accept the will of a majority of the people of Ireland (All-Party Anti-Partition Conference, 1949: 16).

Although there were signs of a thaw in the North-South relationship in the 1960s, with reciprocal visits by the Irish and Northern Irish prime ministers to Belfast and Dublin respectively in 1965, distaste for the border remained deeply ingrained. The dilemma was illustrated in the terms of office of prime ministers Sean Lemass (1959-66) and Jack Lynch (1966-73). The former tried to quietly reconcile two positions: offering de facto recognition to Northern Ireland while retaining the territorial claim. The latter, faced with the reality of civil unrest across the border and pressure to intervene, vacillated between condemning partition and stressing the need to reach agreement with Northern Ireland. 


\section{Norm competition}

By the late 1960s, then, the irredentist line was already being challenged by alternative viewpoints, even if these were still on the political margins. But the outbreak of civil unrest in Northern Ireland that began in late 1968 illustrated the consequences of the generous territory with which Northern Ireland had been endowed in the 1920s: the Catholic minority had increased to $37 \%$ of the population by 1971 , and its age structure indicated that this proportion was likely to grow further (in fact, by 2011 the proportion of the population from a Catholic background was 45\%; Coakley, 2015: 41-5). This minority suffered structural disadvantage as well as being discriminated against by successive unionist governments. The classical Westminster government-opposition system resulted in permanent exclusion from office of the leaders of the Catholic community, represented mainly by the Nationalist Party until 1969, and by the new Social Democratic and Labour Party (SDLP) subsequently. Alongside this, a new Sinn Féin party and its ally, the Irish Republican Army (IRA), began a campaign to destabilise the state and ultimately to procure a united Ireland. The suspension of Northern Ireland's devolved institutions and the introduction of direct British rule in 1972 made necessary the pursuit of a new accommodation, and the British government made it clear that this would be based on unionist-nationalist power sharing and institutionalised links with the Republic. When a deal was finally put in place at the Sunningdale conference in December 1973, it thus included a new Council of Ireland.

The political and socio-economic realities exposed by these changes stimulated new thinking on Northern Ireland, forcing the Irish government to reconsider its stance on Irish unity and pushing the governing party, Fianna Fáil, into undertaking a fundamental re-evaluation of its policy (O’Donnell, 2007: 21-46; Ó Beacháin, 2010; Kelly, 2013: 295-365). A significant reconsideration of Northern Ireland policy also began within the two main opposition parties, which, in any case, had been moving steadily away from the traditional nationalist consensus (Ivory, 1999: 89-90; McDermott, 2014: 102). The southern parties' steep learning curve was marked not so much by a single 'cognitive punch' as by a set of cognitive body-blows, followed by two near-knockouts. The inadequacy of traditional irredentist rhetoric was exposed by a series of developments that forced southern elites to undertake a fundamental reappraisal:

- The incontrovertible fact, demonstrated in a series of elections whose fairness could not be questioned, that a big majority in Northern Ireland rejected the nationalist vision, and was passionately committed to defence of the union and maintenance of partition (Rose, 1971: 188-202)

- The new path taken by Northern Ireland nationalists, of whom some were apparently happy to settle for a reformed Northern Ireland, while others were prepared to engage in a violent struggle to achieve Irish unity, an approach at sharp variance with the position of successive Irish governments (McLoughlin, 2010: 1-5)

- Resistance within the Irish civil service to yielding power and responsibility to pan-Irish political institutions and an apparent preference for the administrative status quo, with some departments seeing the Council of Ireland as 'some kind of external threat to the institutions of the state' (FitzGerald, 1991: 203)

- The burden that would have to be assumed by the Republic in the event of Irish unity, with the financial costs alone threatening to impose a crippling load on the Irish exchequerabout $14-15 \%$ to assume the cost of the British subsidy, and a further $41-44 \%$ if Irish public services were to be upgraded to Northern Ireland levels. ${ }^{3}$

Two other developments fatally punctured the nationalist dream. First, unionists profoundly opposed to any change in the constitutional status quo still possessed sufficient resources to exercise a veto. A political general strike with paramilitary support resulted in the collapse of the new Sunningdale framework in May 1974, and exposed both the reluctance (or inability) of the British government to ensure that normal services would continue in the face of 
determined unionist opposition, and the vulnerability of the Republic to loyalist attack (the worst single incident of the civil conflict, the murder of 33 people in the Dublin and Monaghan bombings of 17 May 1974, was designed to undermine Irish government support for the Sunningdale settlement).

Second, Irish leaders discovered painfully the salience of the maxim 'be careful what you wish for': there were clear signs that the British government was contemplating withdrawal from Northern Ireland in 1974-75, an outcome with which the Irish government believed it would be unable to cope, and which the Foreign Affairs minister described as a 'disaster' (FitzGerald, 2006: 150). Ironically, the prospect of achieving Ireland's irredentist claim was by now a source of worry to the very people who had argued so vociferously for it.

Not surprisingly, then, the Irish government moved in the mid-1970s to a relatively clearly defined policy on Northern Ireland, one it shared in outline with the British government. As the Sunningdale agreement of 1973 had put it, change in the status of Northern Ireland could come about only with the consent of a majority there, implying acceptance of partition in the long term. This was, however, to be subject to two other constitutional principles: devolved government within Northern Ireland on the basis of power sharing between the two communities, and an institutionalised 'Irish dimension' linking Northern Ireland and the Republic. Both governments accepted that progress would be slow, given unionist rejection of the power-sharing arrangements (1974), the failure of a specially convened constitutional convention (1975-76), stalemate in inter-party talks (1980-81), and the reluctance of nationalists - and of many unionists - to engage in a new deliberative assembly (1982-86).

The pursuit of a nationalist consensus on the question of partition continued. The most significant initiative was the New Ireland Forum of 1983-84, which brought together the three major southern parties and the SDLP in a fundamental reappraisal of traditional nationalist objectives. Its report identified three models: joint British-Irish authority over Northern Ireland, a federal or confederal Ireland, and a unitary Irish state. Its stated preference was for the last of these, adopted under pressure from Fianna Fáil leader Charles Haughey as the price for consensus on the Forum report. Nevertheless, in its recognition of political realities in Northern Ireland, the Forum has been hailed as marking 'the beginnings of a profound change of mind and attitude on the part at least of one of the key parties in the imbroglio', nationalist Ireland (MacDonagh, 1985: 169).

Other types of compromise on the Irish-UK border entered the discussion frame during this period. One was a form of repartition that would draw a new line between 'British Ulster' and 'Irish Ulster', though this would leave big minorities on either side (Kennedy, 1990). The second was a British proposal for a new frontier zone-a buffer zone within which both British and Irish security services could operate. This was, however, rejected by the Irish government on the basis that it would aggravate rather than assist already complex crossborder security arrangements (see FitzGerald, 1991: 474-5).

This emerging consensus among southern leaders on a much more modest geopolitical formula was reflected in subsequent developments. Following initial rejection of all three Forum options by British prime minister Margaret Thatcher, a radical new approach was devised in the Anglo-Irish agreement of 1985: the Irish government was given a formal voice in the affairs of Northern Ireland through a new, standing Anglo-Irish Intergovernmental Conference served by a permanent secretariat comprising British and Irish civil servants. Once again, these structures were underpinned by an implicit recognition of the status of Northern Ireland as part of the United Kingdom. Opinion within the major parties quickly consolidated around the 'principle of consent', with even Fianna Fáil amending its constitution to reflect this. These changes were reflected in the work of the Forum for Peace and Reconciliation, created in Dublin in 1994 to involve Sinn Féin in the discussion process. Although consensus was not forthcoming (since Sinn Féin held out for a more nationalist position), its draft final report implied support of the constitutional status quo, in that it supported the notion that 'the exercise of self-determination is a matter for agreement 
between the people of Ireland and must be based on consent' (Forum for Peace and Reconciliation, 1996: Present realities $(\mathrm{k})$ ). Endorsement of the reassuringly positive principles of 'self-determination' and 'consent', does not resolve the difficult and essentially political question as to how these principles should be implemented; as Sir Ivor Jennings (1956: 55-6) warned decades ago, 'the people cannot decide until somebody decides who are the people'.

\section{Norm replacement}

The new consensus achieved in the Good Friday agreement of 1998 (one to which Sinn Féin now assented) represented a decisive change in the Republic of Ireland's relationship with the UK (Cauvet, 2011). It was accompanied by a kind of ideological 'dejustification' of the traditional irredentist position (Kornprobst, 2007b). To start with, it endorsed the land border with the UK with striking solemnity, not merely formally recognising it but amending the Irish constitution to guarantee it. It replaced the irredentist articles 2 and 3 by explicit acceptance of the existing border, 'recognising that a united Ireland shall be brought about only by peaceful means with the consent of a majority of the people, democratically expressed, in both jurisdictions in the island'. It is true that it also provided a mechanism for bringing Irish unity about, but that was a formal gesture without any prospect of short- or medium-term realisation. On the other hand, the agreement did not simply endorse the existing line of the international border; it also made provision for the special status of Northern Ireland, recognising its binational character, and providing for power-sharing institutions, links to the Republic, and other structural changes that expressed the equality of the two traditions.

Since we are concerned here primarily with the Republic of Ireland, the extent to which the agreement found favour outside its borders is of indirect rather than direct relevance. It seems clear, though, that British governments were satisfied with the outcome; they had in any case for long been neutral on the status of Northern Ireland and committed themselves in 1973 to assist the process of Irish unity should a majority there so wish. Within Northern Ireland, unionists were initially divided about the agreement, but most of those who objected were satisfied by the supplementary St Andrews agreement in 2006. Nationalist opinion was overwhelmingly in favour: the agreement was very close to the SDLP's own thinking, and even Sinn Féin has stressed its theoretical border-transforming provisions rather than its geopolitically conservative substantive import.

In the Republic, support for the agreement in the 1998 referendum was overwhelming-94\% voted 'yes' to the constitutional amendment-no doubt assisted by the creative manner in which traditional vocabulary was overhauled so that it could be presented as promoting 'the core ideals of Irish nationalism' (Hayward, 2004: 33). General acceptance of the agreement as definitive is reflected in the absence of debate, during or between election campaigns, on Northern Ireland-related matters, and in the routine implementation of the agreement's provisions for North-South cooperation. As former Taoiseach Bertie Ahern, who played a central role in negotiating the agreement, put it, the matter is now closed, and even majority support for unity within Northern Ireland would of itself be insufficient to trigger a start to the unification process (Coakley, 2015: 51). 


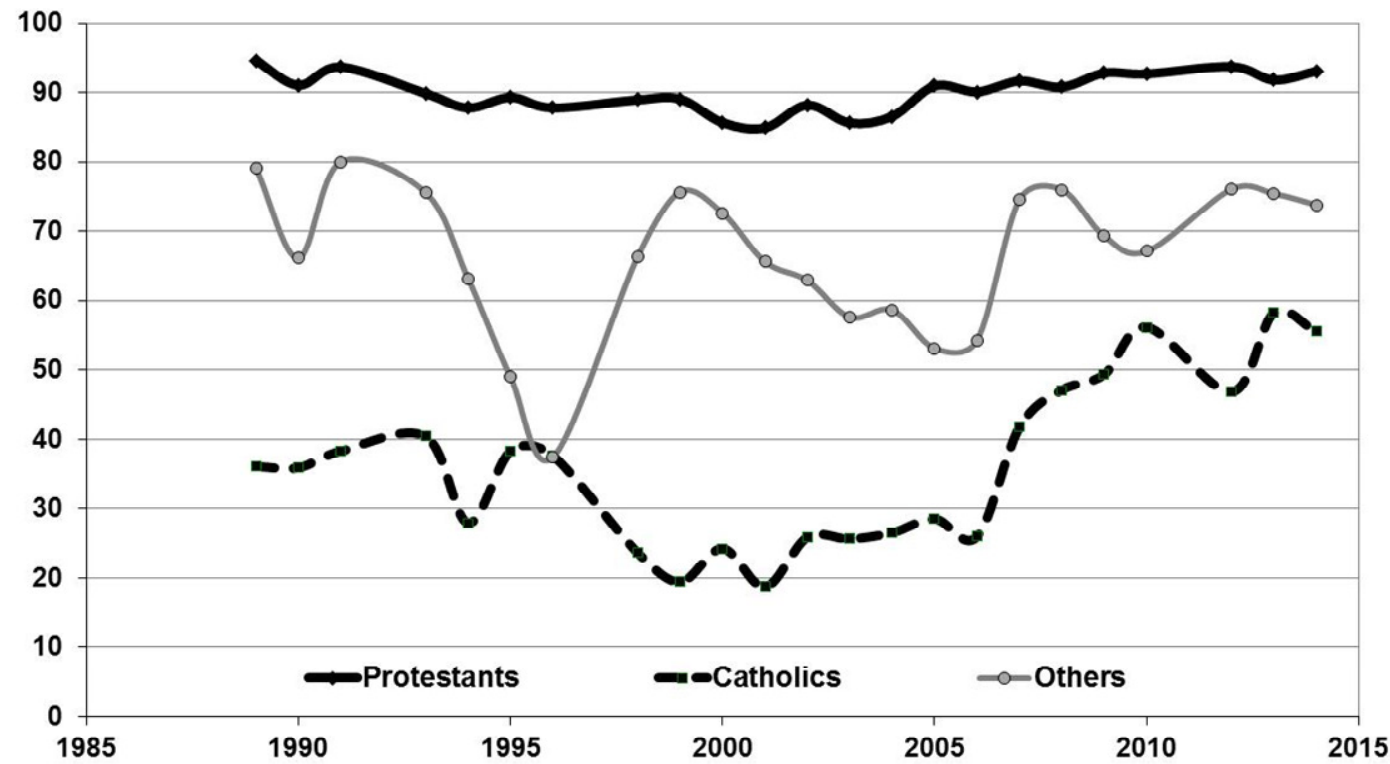

Figure 2. Northern Ireland: support for the Union by religious background, 1989-2014

Note: Responses are to the question 'What do you think the long-term policy for Northern Ireland should be?', with 'remain part of the United Kingdom' as the option reported here. In 2007 the 'pro-UK' response option was divided into two: 'with direct rule' and 'with devolved government'.

Source: Northern Ireland Social Attitudes surveys, 1989-1996; Northern Ireland Life and Times Survey, 19982014; data available www.ark.ac.uk/nilt

By the early twenty-first century, it appeared that consensus had been reached within the Republic of Ireland on the status of the border. The general election of 2016 showed virtually no support for 'dissident' republicans, a result mirrored in the 2016 election to the Northern Ireland Assembly. Levels of politically related violent crime had fallen dramatically by comparison with the late twentieth century. Security monitoring reports indicated that former paramilitary groups had either dissolved or been redirected into other pursuits, such as conventional political activity or 'ordinary' crime. Opinion polls showed continuing support for the status quo, though with many still endorsing support for Irish unity in the long term. The extent to which public opinion in Northern Ireland had moved in a geopolitically conservative direction is illustrated in figure 2, which shows continued overwhelming Protestant support for the Union, but with an increasing proportion of Catholics (by 2010, a majority) also moving to this position. ${ }^{4}$ 


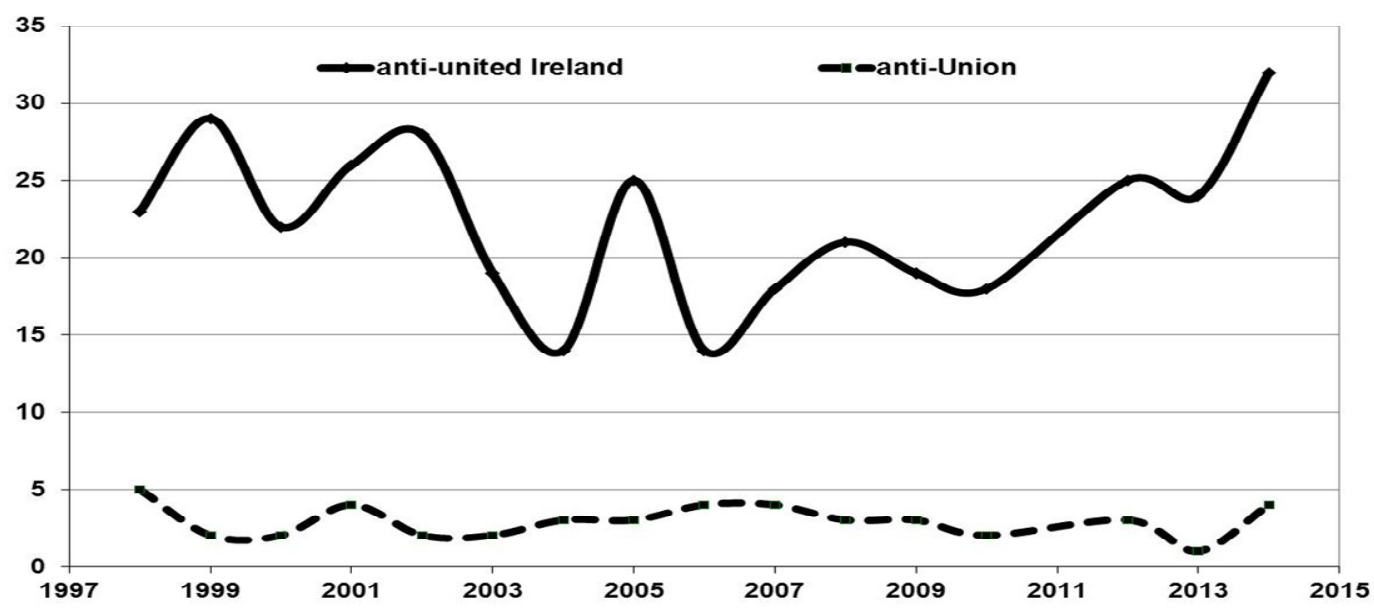

Figure 3. Northern Ireland: resistance to least preferred option by religious background, 1989-2014

\begin{abstract}
Note: Responses are to the question (for Protestant respondents not supporting Irish unity) 'If the majority of people in Northern Ireland ever voted to become part of a United Ireland do you think you would find this almost impossible to accept?', and (for Catholic respondents not supporting the union) 'If the majority of people in Northern Ireland never voted to become part of a United Ireland do you think you would find this almost impossible to accept?'.

Source: Northern Ireland Life and Times Survey, 1998-2014; data available www.ark.ac.uk/nilt
\end{abstract}

This asymmetry in attitudes within Northern Ireland is also to be seen if we look at the intensity of the positions taken. Catholic opponents of the Union, figure 3 suggests, are prepared to live with the status quo, if not actually welcoming it; only $3 \%$, on average, for the period reported here, would find permanent failure to achieve Irish unity 'almost impossible to accept'. Protestant opponents of Irish unity, however, are much more committed to their position, with $22 \%$ reporting Irish unity as 'almost impossible to accept'. This suggests a continuing powerful basis of support within Northern Ireland for the status quo associated with the border, with proponents of traditional irredentism thoroughly marginalised (hardened dissidents of this kind have been evocatively labelled 'norm antipreneurs'; Bloomfield, 2016: 311).

\title{
Northern Ireland as a disputed frontier zone
}

This article has paid little attention to the perspective of one of the two international parties to the Northern Ireland conflict-the United Kingdom, which, as the incumbent state, actually controls Northern Ireland. Notwithstanding the gap between British and Irish priorities that was so pronounced a feature of the negotiation process, tense moments in these negotiation were sometimes examples of shadow boxing, and sometimes real instances of disagreement-but most were potentially resolvable. Shortly before the most fundamental institutional concession by the British, the Anglo-Irish agreement of 1985, Prime Minister Thatcher remarked that 'the Irish want more than we can give and always will'. ${ }^{5}$ In reality, though, there were times when the British were prepared to give more than the Irish were prepared to accept. There was a long tradition of sympathy for Irish nationalism in the British Labour Party, and by 1973 the Conservative Party had also arrived at a point where generous concessions to Irish nationalism were possible. This transition was facilitated by the tendency to see Northern Ireland as a last vestige of empire-a territory with which, unlike Scotland and Wales, the state could comfortably part. The colonial ideology that had been such a safeguard for Northern Ireland at the beginning of the twentieth century had 
suffered a 'normative death' by the century's end (see Panke and Petersohn, 2016: 14-15). Furthermore, retraction from empire was accompanied by a 'signalling' system that highlighted the possibility of further withdrawal (see Chad and Owsiak, 2016: 427)-a reassuring sing to opponents of British rule.

It was, then, primarily on the Irish side that ideological shift was so dramatically evident. The process of normalisation matched closely the model of inter-state conflict resolution over international borders outlined at the beginning of this article. Indeed, the three phases discussed here were reflected in three episodes of fully-fledged cross-party consultation: the All-Party Anti-Partition Conference (1948-73) with its uncritical acceptance of the irredentist norm, the New Ireland Forum (1983-84) as host of a debate on the merits of competing norms, and the Forum for Peace and Reconciliation (1994-96) with its implicit acceptance of the status quo norm. In its first phase, the irredentist norm was deeply embedded in elite discourse and in public opinion. The outbreak of civil unrest in Northern Ireland after 1968, however, delivered a series of 'cognitive punches' to this norm: it appeared to ignore the reality of northern unionist opinion, to be unaware of the subtle changes in northern nationalist attitudes, to take for granted popular and elite support in the Republic, and to fail to consider the enormous costs-financial and other-of change in the status quo. In particular, the Ulster Workers' Council strike in 1974 that brought down the Sunningdale agreement and the very real prospect that the British government would withdraw from Northern Ireland represented a cognitive knock-out.

The great alternative to the irredentist norm was, as in other such disputes, the status quoin the Irish case, hidden behind 'the principle of consent'. From its first hesitant articulation at Sunningdale in 1973, this principle steadily asserted itself as the new norm. It was possible to disguise the reality of the gap between the two norms by arguing that they were mutually compatible. While this was the case in theory, empirical realities suggested that unity would not be brought about by agreement. Nevertheless, in a choice between a combination of irredentism with violence and a combination of the territorial status quo with democratic decision making, the latter was likely to win a rapid victory. It seems clear that the political violence of the 1970s and 1980s pushed public and elite opinion in the Republic decisively in the direction of support for the territorial status quo. The New Ireland Forum of 1983-84 may well have represented the 'tipping point' in this respect, since it forced even adherents of traditional irredentism to come to terms with a new political world-an adjustment that culminated in the victory of the new norm with the Good Friday agreement of 1998.

Apparently insignificant gestures and words often symbolise major changes. The Anglo-Irish agreement of 1985 was, like earlier treaties between Dublin and London, drawn up 'in two originals', rather than (as with other international treaties) 'in duplicate'. While the content of the body of the text was identical, the Irish version was labelled a treaty between 'the Government of Ireland' and 'the Government of the United Kingdom'. The British version, however, was entitled a treaty between 'the Government of the United Kingdom of Great Britain and Northern Ireland' and 'the Government of the Republic of Ireland'. The gap in respect of territorial claims was such that the two sides could not agree even on the designation of the other state (Coakley, 2009). The 1998 Good Friday agreement changed that; the subsequent enabling treaty was designated by both sides as being between 'the Government of Ireland' and 'the Government of the United Kingdom of Great Britain and Northern Ireland', signalling full normalisation of the international border.

\section{Conclusion}

As suggested above, 'liberal' or economic approaches are of limited value in accounting for the Irish-British settlement. Realist interpretations have more to offer, and can be accommodated within the constructivist approach adopted here. It has been argued above that the norm competition model offers an invaluable insight into the process of evolution by which the Republic of Ireland accepted the existing land border with the United Kingdom, but 
this case study also has important implications for the model itself. Six important findings may be highlighted.

The first is the phenomenon of ideological reversal: elites and opinion formers are driven to assume new ideological positions almost in the manner of Paul on the road to Damascus. The 'cognitive punch' that leads to reassessment of the original norm may be more like a 'cognitive knock-out' at the end of a bruising encounter. The Irish government and political elites were forced in the early 1970 s to encounter uncomfortable existing circumstances and new realities that rendered the irredentist claim not just of questionable strategic value but also of menacing import for the state itself: the Republic of Ireland was simply in no condition to assume responsibility for the economic and security costs of Northern Ireland. This undermined the irredentist demand more speedily and effectively than would otherwise have been explicable - perhaps aided by the capacity of elites to hide the extent of pragmatic shift from their more conservative supporters, as in elite-mass tensions about foreign policy elsewhere among Europe's neutral states (Beyer and Hofmann, 2011: 291).

Second, notwithstanding the sharp changes just described, a negotiation process may feature incremental advance rather than sudden settlement. This is not a reference to creeping progress, but to step-wise agreement. It has been observed that many successful settlements have worked because they have operated in stages (referring to segments of the frontier), with settlement of one stage allowing negotiators to move on to the next (Mattes, 2016). In complex settlements, such as that of Northern Ireland, the stages were not successive border segments, but themes, such as the British-Irish relationship, the NorthSouth relationship and relationships between the two communities within Northern Ireland, where separate negotiations, and even stages in negotiation, were possible.

Third, conflicts can be redefined and moved from the political to the 'metaconstitutional' level in a form of discourse displacement: they can be resolved simply by being sidelined, or 'kicked upstairs' to the level of constitutional abstraction. Stability can be secured in the absence of normalisation (seen as implying formal acceptance of the border). By the end of the 1960s a modus vivendi between Irish and British governments had already been reached. The territorial dispute could effectively be ignored apart from a few rare legal and social contexts. Territorial claims implied in names (such as 'Ireland', rejected by the British, and 'United Kingdom of Great Britain and Northern Ireland', rejected by the Irish) could be creatively overlooked by such formulas as completing international documents in two originals rather than in duplicate, and truncating the title of the head of state when official encounters were unavoidable (when the first ever official visit of an Irish President to Great Britain took place in 1993, she was referred to simply as 'President Mary Robinson', without mention of the state over which she presided). Membership of the EU since 1973 also contributed to a normalisation of relations such that the irritant of Ireland's constitutional claim on part of the territory of the UK could effectively be ignored. There is no reason to assume that this approach could not have continued indefinitely, had it not been disturbed by the outbreak of civil unrest in Northern Ireland. Ireland's territorial claim might have been formally retained but in practice marginalised as an historical anomaly, comparable with ornamental but vacuous claims in royal titles, such as that of the Swedish king until 1973 (over the Goths and the Wends), or the British King until 1801 (when the title 'King of France' was formally renounced).

Fourth, a territorial dispute is rarely, if ever, a matter of concern only to the parties to the conflict at international level; it may also be driven by frontier disturbance. The population of the disputed territory may be a vital actor-sometimes, perhaps, even more central a player than the contending powers. It was the outbreak of civil unrest in Northern Ireland that defined the context for the 'cognitive punches' that so effectively punctured the Irish irredentist norm. The views of the people of Northern Ireland are formally seen by the two governments as driving its future status, and the Good Friday agreement makes specific provision for this. If a pro-Irish unity majority were to emerge in a referendum, Northern 
Ireland would move from position $\mathrm{H}$ to position $\mathrm{J}$ in figure 1 , with the agreement now guaranteeing the position of the unionist minority.

Fifth, boundary claims are not part of a zero-sum process; a disputed territory need not be included in its entirety in one state but rather is subject to a process of border reconstitution. It may be partitioned between the claimants, or the claimants may exercise joint sovereignty over it. In either case, the formula need not be one of finding a median compromise; the compromise may be tilted in favour of one state or the other, and, as the Northern Ireland case illustrates, a wide variety of innovative institutional mechanisms (including local power sharing) may form part of the settlement package. Furthermore, a 'hard' border may be made 'softer'. The British-Irish border has been transformed since 1998, as new institutions that promote cross-border cooperation and the impact of EU programmes render it less visible on the administrative, political and economic maps (Tannam, 2007b: 121-3; Coakley and O'Dowd, 2007: 882).

Finally, a 'settlement' may deliver no more than contingent stability. Rather than being definitive, it may constitute essentially a formula for compromise, or, indeed, for geopolitical change. The Northern Ireland settlement is an example: it provides a flexible mechanism for territorial transfer should this be 'democratically' supported. But a transfer of territory might also occur for other reasons iin the Irish case, depending on the dynamics of internal British politics. In particular, the decision of British voters in June 2016 to leave the EU while the Republic of Ireland continues to be a member has reopened the question of the Irish border, raising a range of unpredictable possibilities (Tannam, 2016). Neither should the possibility of collapse of the 1998 agreement for other reasons be discounted: it has been plausibly argued that the agreement was insufficiently embedded in stable, widely accepted constitutional principles within Northern Ireland itself, relying instead on ad-hoc intervention by the British and Irish governments, a fragile formula that depends on continuous oversight from Dublin and London that is unlikely to be forthcoming (Todd, 2016a).

This analysis of the displacement of the irredentist norm in Ireland by a territorial status quo one raises, then, important considerations for the construction of theoretical approaches to the resolution of international boundary disputes. Much of the literature obviously draws its inspiration from Thomas Kuhn's (1962) path-breaking analysis of revolutionary processes in scientific research. There are important respects in which the three stages of the model used here to illuminate change in respect of the Irish border run parallel to the kind of paradigm shifts that Kuhn saw as driving scientific research, as an old paradigm increasingly failed to account satisfactorily for empirical reality, but was nevertheless adhered to until such time as an alternative paradigm proved more capable of coping with this reality. A central conclusion of Kuhn's work was, however, that paradigm replacement is a continuing process. We would thus need to be careful not to conclude definitively that the displacement of the irredentist norm by the status quo one is the end of the story.

\section{Acknowledgement}

Revised version of a paper presented at the annual conference of the Political Studies Association of Ireland, Cork, 16-18 October, 2015. I am grateful to conference participants, Noel Dorr, Jennifer Todd and the anonymous referees for comments on an earlier draft.

\section{Notes}

1. The three sets of relationships (nationalist-unionist within Northern Ireland, North-South within the island of Ireland, and British-Irish) are inextricable, but governed by different dynamics; for an exploration of the extent to which the 1998 settlement was shaped by a rupture of pathdependent patterns of ethnic competition, see Ruane and Todd, 2007.

2. To set these parties in context, Fianna Fáil and its predecessor won $44 \%$ of all parliamentary seats over the period 1922-2016, Fine Gael and its main predecessor 33\%, and the Labour Party $11 \%$. The remaining $12 \%$ is accounted for by small parties and non-aligned deputies. 
3. These estimates are for 1969; National Archives of Ireland, Interdepartmental Unit on Northern Ireland, Interim report (final version), June 1973, appendix 5: finances, TSCH/2004/21/624.

4. A change in the options offered from 2007 onwards is likely to have inflated support for the Union.

5. Charles Powell to Sir Robert Armstrong, 2 Jan. 1985, Prime Minister's Papers, The National Archives (Kew), PREM 19/1548.

\section{References}

Abulof, $U$ (2016) We the peoples? The strange demise of self-determination. European Journal of International Relations 22 (3): 536-565.

Ackerman, B (1992) The Future of Liberal Revolution. Hartford, CT: Yale University Press.

All-Party Anti-Partition Conference (1949) Ireland's Right to Unity: The Case Stated by the All-Party Anti-Partition Conference, Mansion House, Dublin, Ireland. 2nd ed. Dublin: Mansion House Committee.

Aughey, A (1989) Under Siege: Ulster Unionism and the Anglo-Irish Agreement. London Hurst.

Beyer, JL and Hofmann, SC (2011) Varieties of neutrality: norm revision and decline. Cooperation and Conflict 46 (3): 285-311.

Blake, G (1996) Some lessons from the 1924-25 Irish Boundary Commission. IBRU Boundary and Security Bulletin 3 (4): 55-58.

Bloomfield, A (2016) Norm antipreneurs and theorising resistance to normative change. Review of International Studies 42 (2): 310-33.

Bradley, J (2007) The island economy: Ireland before and after the Belfast agreement. In: Coakley, J and O'Dowd, L (eds), Crossing the Border: New Relationships between Northern Ireland and the Republic of Ireland. Dublin: Irish Academic Press, pp. 61-86.

Cauvet, P (2011) Deterritorialisation, reterritorialisation, nations and states: Irish nationalist discourses on nation and territory before and after the Good Friday Agreement. Geojournal, 76 (1): 77-91.

Clay, KC and Owsiak, AP (2016) The diffusion of international border agreements. Journal of Politics 78 (2): 427-42.

Coakley, J (2009) 'Irish Republic', 'Eire' or 'Ireland'? The contested name of John Bull's other island'. Political Quarterly 80 (1): 49-58.

Coakley, J (2012) Nationalism, Ethnicity and the State: Making and Breaking Nations. London: Sage.

Coakley, J (2015) 'Does Ulster still say 'no'? Public opinion and the future of Northern Ireland'. In: Elkink, J and Farrell, D (eds), The Act of Voting: Identities, Institutions and Locale. London: Routledge, pp.35-55.

Coakley, J and O'Dowd, L (2007) The transformation of the Irish border. Political Geography 26 (8): 877-885.

Coughlan, A (1990) A unitary Irish state. In: McGarry and O'Leary, 1990, pp. 48-68.

Dent, M (1988) The feasibility of shared sovereignty (and shared authority). In: Townshend, C (ed.), Consensus in Ireland: Approaches and Recessions. Oxford: Clarendon Press, pp. 128-156. 
Dragneva, R and Wolczuk, K (2015) Ukraine between the EU and Russia: The Integration Challenge. Basingstoke: Palgrave Macmillan.

Finnemore, M and Sikkink, K (1998) International norm dynamics and political change. International Organization, 52 (4), pp 887-917.

FitzGerald, G (1991) All in a Life: Garrett FitzGerald: An Autobiography. London: Macmillan.

FitzGerald, G (2006) The 1974-5 threat of a British withdrawal from Northern Ireland. Irish Studies in International Affairs 17: 141-150.

Forsberg, T (1998) Settled and remaining border issues around the Baltic Sea. In: Hedegaard, L et al (eds), The Nebi Yearbook 1998. Berlin: Springer, pp. 48-68.

Forum for Peace and Reconciliation (1996) Paths to a Political Settlement: Realities, Principles and Requirements. Final Paper of the Drafting Committee of the Forum for Peace and Reconciliation. Dublin: Forum for Peace and Reconciliation. Available web.archive.org/web/19991002025634/http://www.fusio.ie/web1/forum/final.html.

Gallagher, F (1957) The Indivisible Island: The History of the Partition of Ireland. London: Gollancz.

Goertz, G and Diehl, PF (1992) Territorial Changes in International Politics. London: Routledge.

Grote, G (2012) The South Tyrol Question, 1866-2010: From National Rage to Regional State. Oxford: Peter Lang.

Guo, R (2012) Territorial Disputes and Conflict Management: The Art of Avoiding War. London: Routledge.

Hayes, P (1998) Parallel governments: an option for Northern Ireland. Regional and Federal Studies 8 (3): 89-103.

Hayward, K (2004) The politics of nuance: Irish official discourse on Northern Ireland. Irish Political Studies 19 (1): 18-38.

Hayward, K (2006) Reiterating national identities: the European Union conception of conflict resolution in Northern Ireland. Cooperation and Conflict 41 (3): 261-284.

Hayward, K (2009) Irish Nationalism and European Integration: The Official Redefinition of the Island of Ireland. Manchester: Manchester University Press.

Hepburn, E (2014) Forging autonomy in a unitary state: the Åland Islands in Finland. Comparative European Politics 12 (4): 468-487.

Ivory, G (1999) Revisions in nationalist discourse among Irish political parties. Irish Political Studies 14 (1): 84-103.

Jennings, Sir I (1956) The Approach to Self-Government. Cambridge: Cambridge University Press.

Kelly, S (2013) Fianna Fáil, Partition and Northern Ireland,1926-1971. Dublin: Irish Academic Press.

Kennedy, L (1990) Repartition. In: McGarry and O'Leary, 1990, pp. 137-161.

Kenny, A (1990) Joint authority. In: McGarry and O'Leary, 1990, pp. 219-241.

Knox, C (2010) Devolution and the Governance of Northern Ireland. Manchester: Manchester University Press.

Kornprobst, M (2007a) Argumentation and compromise: Ireland's selection of the territorial status quo norm. International Organization 61 (1): 69-98. 
Kornprobst, M (2007b) Dejustification and dispute settlement: irredentism in European politics. European Journal of International Relations 13 (4): 459-487.

Kuhn, TS (1962) The Structure of Scientific Revolutions. Chicago: University of Chicago Press.

MacDonagh, O (1985) What was new in the New Ireland Forum?. The Crane Bag 9 (2): 166170.

Mattes, M (2016) 'Chipping away at the issues': piecemeal dispute resolution and territorial conflict. Journal of Conflict Resolution, 2016, electronic preprint DOI: 10.1177/0022002716640899.

McCall, C (2011) Culture and the Irish border: spaces for conflict transformation. Cooperation and Conflict 46 (2): 201-221.

McCall, C (2014) The European Union and Peacebuilding: The Cross-Border Dimension. Basingstoke: Palgrave Macmillan.

McDermott, S (2014) The dimensions of Irish government involvement in the pursuit of a settlement of the Northern Ireland conflict. Irish Political Studies 29 (1): 98-115.

McGarry, J and O'Leary, B (1990) Conclusion: Northern Ireland's options: a framework for analysis. In: McGarry and O'Leary, 1990, pp. 268-303.

McGarry, J and O'Leary, B (1990) The Future of Northern Ireland. Oxford: Clarendon Press.

McLoughlin, PJ(2010) John Hume and the Revision of Irish Nationalism. Manchester: Manchester University Press.

Moore, M and Crimmins, J (1990) The case for negotiated independence. In: McGarry and O'Leary, 1990, pp. 242-267.

Ó Beacháin, D (2010). The Destiny of the Soldiers: Fianna Fail, Irish Republicianism and the IRA 1926-1973. Dublin: Gill \& Macmillan.

O'Donnell, C (2007) Fianna Fáil, Irish Republicanism and the Northern Ireland Troubles, 1968-2005. Dublin: Irish Academic Press.

O'Leary, B, Lyne ,T, Marshall, J and Rowthorn, B (1993) Northern Ireland: Sharing Authority. London: Institute for Public Policy Research.

Oberdörfer, L (2004) The Danzig question in British foreign policy, 1918-1920. Diplomacy and Statecraft 15 (3): 573-592.

Palley, C (1990) Towards a federal or confederal Irish state. In: McGarry and O'Leary, 1990, pp. 69-99.

Panke, D and Petersohn, U (2016) Norm challenges and norm death: the inexplicable?. Cooperation and Conflict 51 (1): 3-19.

Rankin, KJ (2007) Deducing rationales and political tactics in the partitioning of Ireland, 1912-1925. Political Geography 26 (8): 909-33.

Roberts, H (1987) Sound stupidity: the British party system and the Northern Ireland question. Government and Opposition 22 (3): 315-335.

Rose, R (1971) Governing without Consensus: An Irish Perspective. London: Faber and Faber.

Rose, R (1976) Northern Ireland: A Time of Choice. London: Macmillan.

Ruane, J and Todd, J (2007) Path dependence in settlement processes: explaining settlement in Northern Ireland. Political Studies 55 (2): 443-458. 
Samuels, JH (2007) Condominium arrangements in international practice: reviving an abandoned concept of boundary dispute resolution. Michigan Journal of International Law 29: 727-776.

Schultz, KA (2015) Borders, conflict, and trade. Annual Review of Political Science 18: 12545.

Simmons, BA (2005) Rules over real estate: trade, territorial conflict, and international borders as institutions. Journal of Conflict Resolution, 49 (6): 823-848.

Tannam, E (2001) Explaining the Good Friday Agreement: a learning process. Government and Opposition 36 (4): 493-518.

Tannam, E (2007a) The European Commission's evolving role in conflict resolution: the case of Northern Ireland 1989-2005. Cooperation and Conflict 42 (3): 337-356.

Tannam, E (2007b) Public policy: the EU and the Good Friday agreement. In: Coakley, J and O'Dowd, L (eds), Crossing the Border: New Relationships between Northern Ireland and the Republic of Ireland. Dublin: Irish Academic Press, pp. 104-124.

Tannam, E (2016) Brexit and the Future of the United Kingdom. Rome: Istituto Affari Internazionali [IAI working papers 16/16].

Todd, J (2014) Thresholds of state change: changing British state institutions and practices in Northern Ireland after direct rule. Political Studies 62 (3): 522-38.

Todd, J (2016a) Contested constitutionalism? Northern Ireland and the British-Irish relationship since 2010. Parliamentary Affairs, online preprint doi:10.1093/pa/gsw019.

Todd, J (2016b) Northern Ireland: timing and sequencing of post-conflict reconstruction and peacebuilding. In Langer, A and Brown, GK (eds), Building Sustainable Peace: Timing and Sequencing of Post-Conflict Reconstruction and Peacebuilding. Oxford: Oxford University Press

Whyte, J (1990) Interpreting Northern Ireland. Oxford: Clarendon Press.

Wiegand, KE (2011) Enduring Territorial Disputes: Strategies of Bargaining, Coercive Diplomacy, and Settlement. Athens, GA: University of Georgia Press.

Wiskemann, E (1967) Czechs and Germans: A Study of the Struggle in the Historical Provinces of Bohemia and Moravia. 2nd ed. London: Macmillan.

Wolff, S (2003) Disputed Territories: The Transnational Dynamics of Ethnic Conflict Settlement. New York: Berghahn.

Wolff, S (2008) Complex power sharing as conflict resolution: South Tyrol in comparative perspective. In: Woelk, J, Palermo, F and Marko, J (eds), Tolerance through Law: SelfGovernance and Group Rights in South Tyrol. Leiden: Martinus Nijhoff, pp. 329-370.

Zacher, MW (2001) The territorial integrity norm: international boundaries and the use of force. International Organization 55 (2): 215-250. 